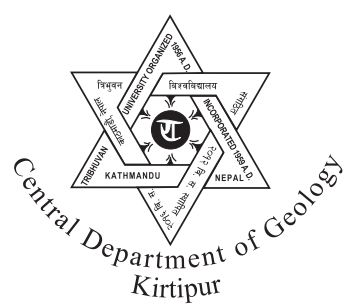

\title{
Evaluation of quality of crushed-limestone and -siltstone for road aggregates
}

\author{
*Shrawan Khanal and Naresh Kazi Tamrakar \\ Central Department of Geology, Tribhuvan University, Kirtipur, Kathmandu, Nepal
}

\begin{abstract}
Aggregates are important constituents of pavement structures. Performance of aggregate layers depends on particle shape, grading and composition and their physical, mechanical and chemical properties. Careful study of these properties allows evaluation of aggregates according to the international norms. There are huge rock outcrops surrounding the Kathmandu Valley. With growing construction in and around the Kathmandu Valley, demand of aggregates has become so high that limited quarry sites within the valley are not sufficient to meet the requirements. Therefore, search of rock outcrops from which suitable aggregates may be quarried is sought to meet the current and future demands of aggregates suitable not only for the building and infrastructures but also for the roads or transport networks in the country. This study aims in exploring and evaluating suitability of natural crushedrock aggregates in western Kathmandu, Nepal for unbound pavement structures.

Mainly three kinds of rocks were identified from the outcrops of the study area; siliceous limestone, crystalline limestone and calcareous siltstone. Shape factor $(\mathrm{F})$ ranges from 0.99 to 1.40 in most of the samples indicating their cubic to disc shape. Aggregates have high roughness indices and moderate roundness indices. Flakiness indices of the test samples vary from $14 \%$ to $25 \%$ and elongation indices from 75.49 to $90.79 \%$ indicating that the crushed samples yield very little flat and elongated particles, and huge equant particles, which is very desirable for aggregates.

Dry density of samples ranges from 2495 to $2658 \mathrm{~kg} / \mathrm{m}^{3}$. WAV varies from 0.20 to $0.67 \%$. ACV ranges from $22-26 \%$ and aggregates are strong enough to resist against compressive load. LAA varies from 27 to $30 \%$ and AIV ranges from 10 to $14 \%$ showing that the aggregates have good hardness. The average CBR value is $61.12 \%$. SSV ranges from 4.37 to $11.64 \%$. All these indices meet the BS standard, American standard and Nepal standard, and are acceptable for road base and sub base courses of unbound pavement in roads.
\end{abstract}

\section{INTRODUCTION}

Aggregates form the major part of the pavement structures and are the prime materials used in pavement construction. Aggregates used in contest of Nepal are natural deposits of sand and gravel and crushed stones. Aggregates used in road construction have to primarily bear load stresses occurring on the roads and runways and have to resist wear due to abrasive action of traffic. The performance of aggregate layer depends on its intrinsic properties, i.e. the particle shape, grading, composition and its

*Corresponding author:

E-mail address: kumarsarban@yahoo.mail.com physical, mechanical and chemical properties. Therefore, selection of aggregates depends on these properties and specification set by national and international norms. Works on aggregates and their properties have been made earlier in different areas by several authors (Tamrakar et al. 1999; Maharjan and Tamrakar 2003; Thapaliya 2005; Dhakal et al. 2006; Maharjan and Tamrakar 2007; Tamrakar et al. 2007). Tamrakar et al. (1999) suggested that the mechanical properties of sandstones depended on the rocktypes and content of calcium carbonate cement, and were independent on deposition age of rocks. Maharjan and Tamrakar (2003) evaluated quality of siltstone samples from the Tistung 


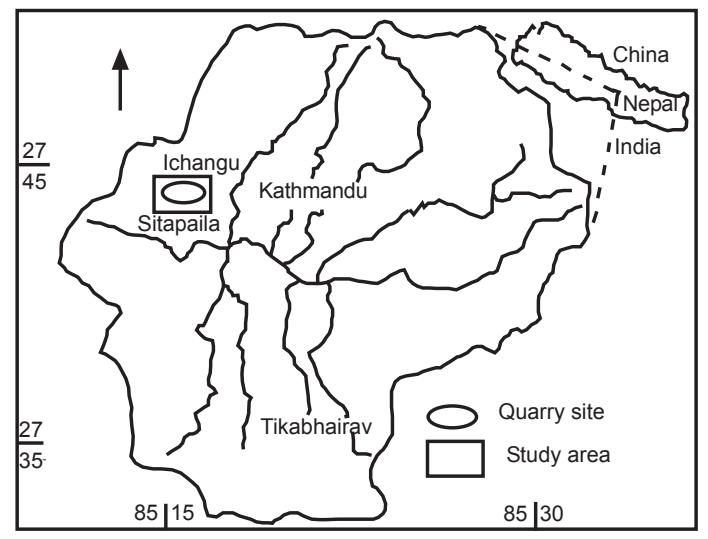

Fig. 1 A map showing location of the study area

Formation for concrete aggregate and found that the aggregates were appropriate for concrete aggregates. Thapaliya (2005) studied limestones of the Chandragiri Formation, southern Kathmandu, and showed that the rocks were medium to high strength, durable and suitable for both monumental and construction purposes. Dhakal et al. (2006) conducted freeze-thaw experiments on limestones, sandstones, dolomite and schist, and concluded that initiation and extension of cracks and subsequent wearing and deterioration occurred relatively faster in the rock having a high porosity, and the durability of freezing-thawing was greatly influenced by mineralogy. Maharjan and Tamrakar (2007) evaluated quality of the river gravels for aggregates and concluded that the majority of gravels had diverse chemical groups, high durability and good workability for road and concrete aggregates. Tamrakar et al. (2007) analysed sandstones from the Siwalik group and concluded that the strength of the sandstones depended primarily on proportion of void space in sandstones.

The Cambrian rocks of the Chandragiri Formation (Stocklin 1980) are well distributed in the western watershed of the Kathmandu Valley (Fig.1), in Adeshwor area. Among the several quarries operated in the peripheral part of the Kathmandu Valley, natural crushed rock aggregates from Adeshwor area are being supplied to the market without any technical specification. Therefore, this study aims in exploring and evaluating the suitability of natural crushed-rock aggregates for unbound pavement structure.

\section{PAVEMENT STRUCTURES}

In most of the roads the natural soil is seldom strong enough to support the repeated application of even modest wheel loads without significant deformation. It is therefore necessary to interpose between the wheel and soil structure to supplement the natural strength of soil formation. The structure thus constructed is called "pavement".

According to "Design and Evaluation of Rigid and Flexible pavement TRR (1990)" pavement profiles can be of two-layer, three-layer and four-layer profiles. "The design and performance of road pavements, London (1991)" traditionally classified pavements as:

(i) Flexible consisting of compacted stone beneath a bituminous surfacing. Modern flexible pavement consists of three layers, i.e. bituminous surfacing, road base and sub base as in Fig. 2a. The surfacing is generally subdivided into a wearing course and base course laid separately. The base and sub base may also be laid in composite forms using different materials and are designated upper and lower road base or upper and lower sub bases as in Fig $2 b$.

(ii) Rigid or concrete of a concrete slab lays either directly on the soil or on a shallow granular bed. Concrete pavements normally consist of only concrete slab and the sub base, but a bituminous surfacing may be added at a time of construction or later (Fig. 3).

Different types of pavement are constructed on roads for safe and comfortable movements of vehicles at the desired speed. The standard nomenclature of the pavement used in Nepal consists of following

\begin{tabular}{|l|}
\hline Surfacing \\
\hline Road base \\
\hline Sub base \\
\hline Sub grade \\
\hline
\end{tabular}

(a)

\begin{tabular}{|l|}
\hline Wearing course \\
\hline Base course \\
\hline Upper road base \\
\hline Lower road base \\
\hline Upper sub base \\
\hline Lower subbase \\
\hline Sub grade \\
\hline
\end{tabular}

(b)
Fig. 2 Components of flexible pavement: (a) Simple four-layer pavement and (b) More details of the four-layer pavement. 


\begin{tabular}{|l|}
\hline Concrete slab \\
\hline Sub base \\
\hline Sub grade \\
\hline
\end{tabular}

\begin{tabular}{|c|}
\hline $\begin{array}{c}\text { Bituminous } \\
\text { surfacing }\end{array}$ \\
\hline Concrete slab \\
\hline Sub base \\
\hline Subgrade \\
\hline
\end{tabular}

Fig. 3 Component of concrete pavement

layers according to the standard specification for road and bridge works DOR (2001) (Fig. 4).

(i) Sub grade deals with the treatment of upper layers of earthworks including preparation and surface treatment of the formation, the addition of layers of selected materials, the improvement of in situ materials by addition and mixing of selected materials or by addition or mixing of lime.

(ii) Sub base consists of granular materials, either naturally occurring or crushed but they may be granular materials stabilized with cement. Materials used in sub base are gravel, sands, silty sand and clayey sand.

(iii) Road base is the main structural component of the road. Its function is to reduce the compressive stresses in the sub grade and the sub base to an acceptable level and to ensure that the magnitude of the flexural stresses in the surfacing will not lead to cracking. Dry single size stone free from clay, organic or other deleterious matter is spread and then filled with fines using vibratory compaction.

(iv) Surfacing includes a wide range of dense and more open and textured material bound with bitumen or tar binders.

Though these layers are the distinct constructive layers in the pavements; structurally pavements are divided in two groups on the basis of presence or absence of them. Pavements are of two types; bound and unbound (Fig. 4). In bound pavements aggregates are bonded by cement or bituminous binders. Unbound is used for sub bases or capping, but else where may be used for base course. In the case of low volume roads the whole structure is considered as unbound pavements. A major difference between them is absence of waring course and binders in case of unbound pavement structure (Fig. 4).

\section{GEOLOGICAL SETTING}

The sampled site, Adeshwar-Kallabari ridge with highest altitude $1606 \mathrm{~m}$ extending SE-NW meets ultimately the Nagarjun Range in the north. The major draining channels are the Jughe Khola in the north and the Lupan Khola in the south of the ridge. The Jughe Khola flows down from the NW direction towards SE with its many small tributaries coming

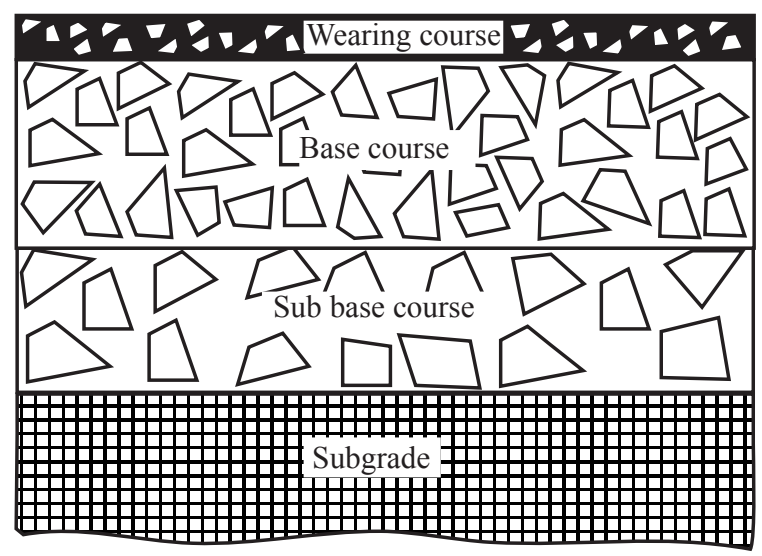

(a)

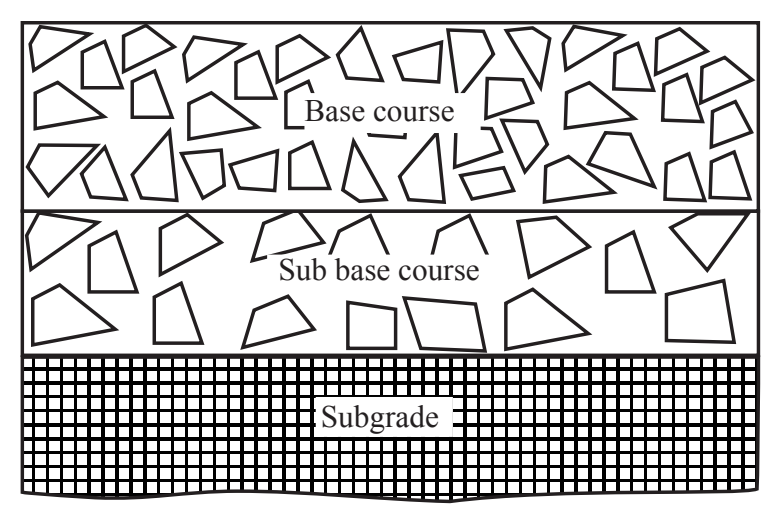

(b)

Fig. 4 Pavements structures (a) Bound pavement, typical flexible pavement construction layers and (b) Unbound pavement 
from north and south. The Lupan Khola flows from the southern part of the ridge with its tributaries from the north and the south. Mainly limestones and siltstones are exposed at the quarry sites. Generally, beds strike NW-SE and dip $40^{\circ} \mathrm{N}$ (Fig. 5). Limestone of the quarry is light grey to grey, medium- to coarsegrained, slight to moderately weathered, well bedded, and highly jointed with yellow to brown weathering color (Fig. 6). Rocks exposed at the quarry area are fresh while those exposed around the quarry are weathered. At the top of the ridge the rocks are weathered and only core stones are developed.

\section{METHODOLOGY}

The study area was surveyed on an scale of $1: 25,000$ to collect information on lithology, geological structure and rock mass characteristics. Seven representative block and fragmented samples from the three different horizons were collected (Fig. 5). Mineralogical and textural properties of rocks were investigated by preparing thin sections and studying under the polarizing microscope and analyzing the images. Cores obtained from the block samples were used for determination of physical and petrographic properties. Fragmented samples were utilized for the

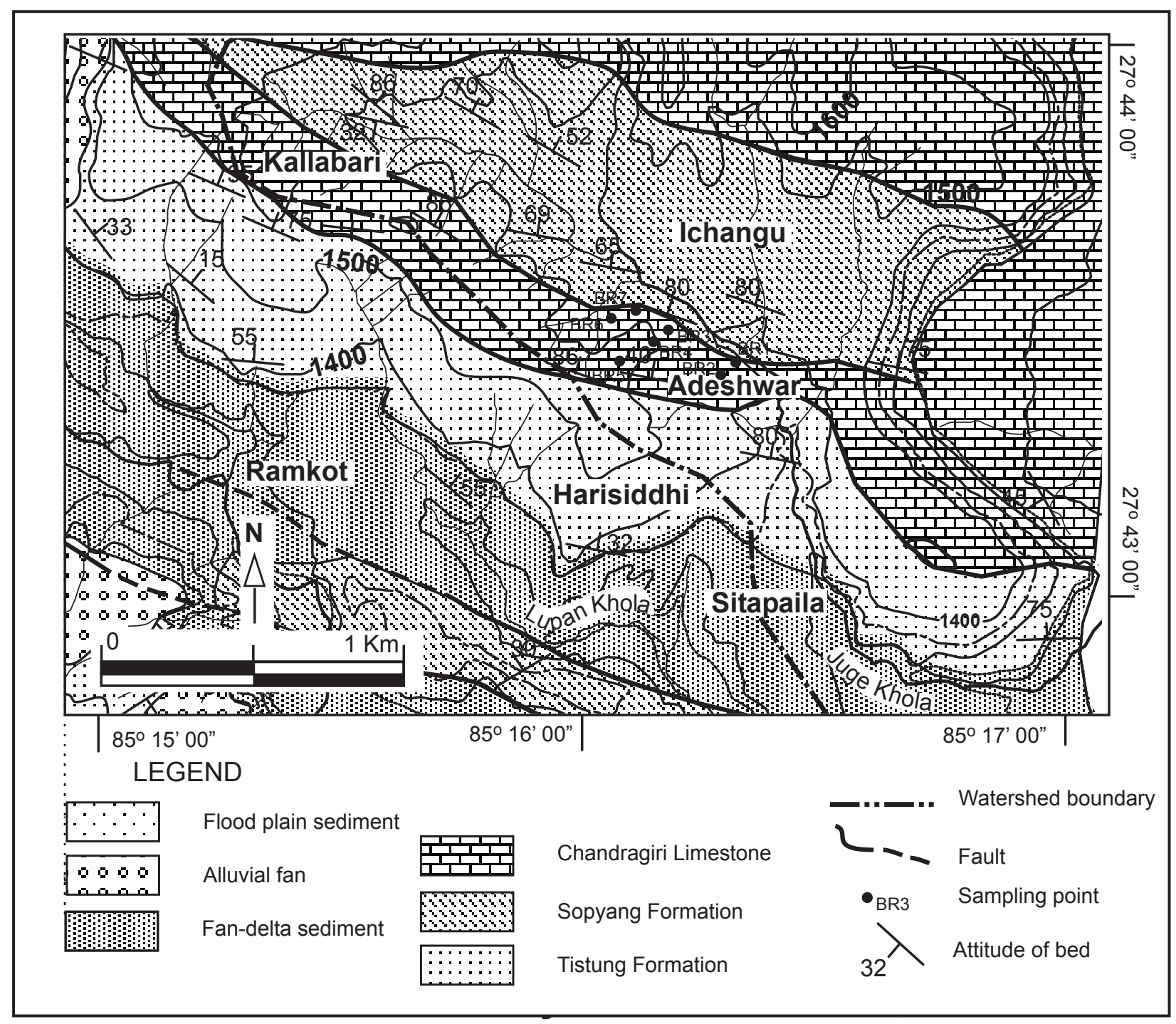

Fig. 5 A geological map showing structure of bedrocks distributed in study area, and the location of sampling sites. 
determination of shape parameters using axial ratios as well as image analysis, and of other mechanical and chemical properties. Chemical analysis of the samples for $\mathrm{CaO}$ and $\mathrm{MgO}$ was also made to find out $\mathrm{CaO} / \mathrm{MgO}$ ratio. The data obtained from the petrographic, physical, mechanical and chemical analyses were used to evaluate the crushed-limestone and siltstone for unbound pavements.

\section{ROCK MASS CHARACTRISTICS}

Discontinuities in the physical continuity of the rocks include bedding surfaces, joints, faults and foliations. Though there are four sets of joints in the rocks, two major joints are prominent particularly in limestones. Major joint sets are vertical (Table 1). Joint spacing varies from $0.3 \mathrm{~m}$ to $3 \mathrm{~m}$ which means joints are moderate to wide spaced. Two major joints
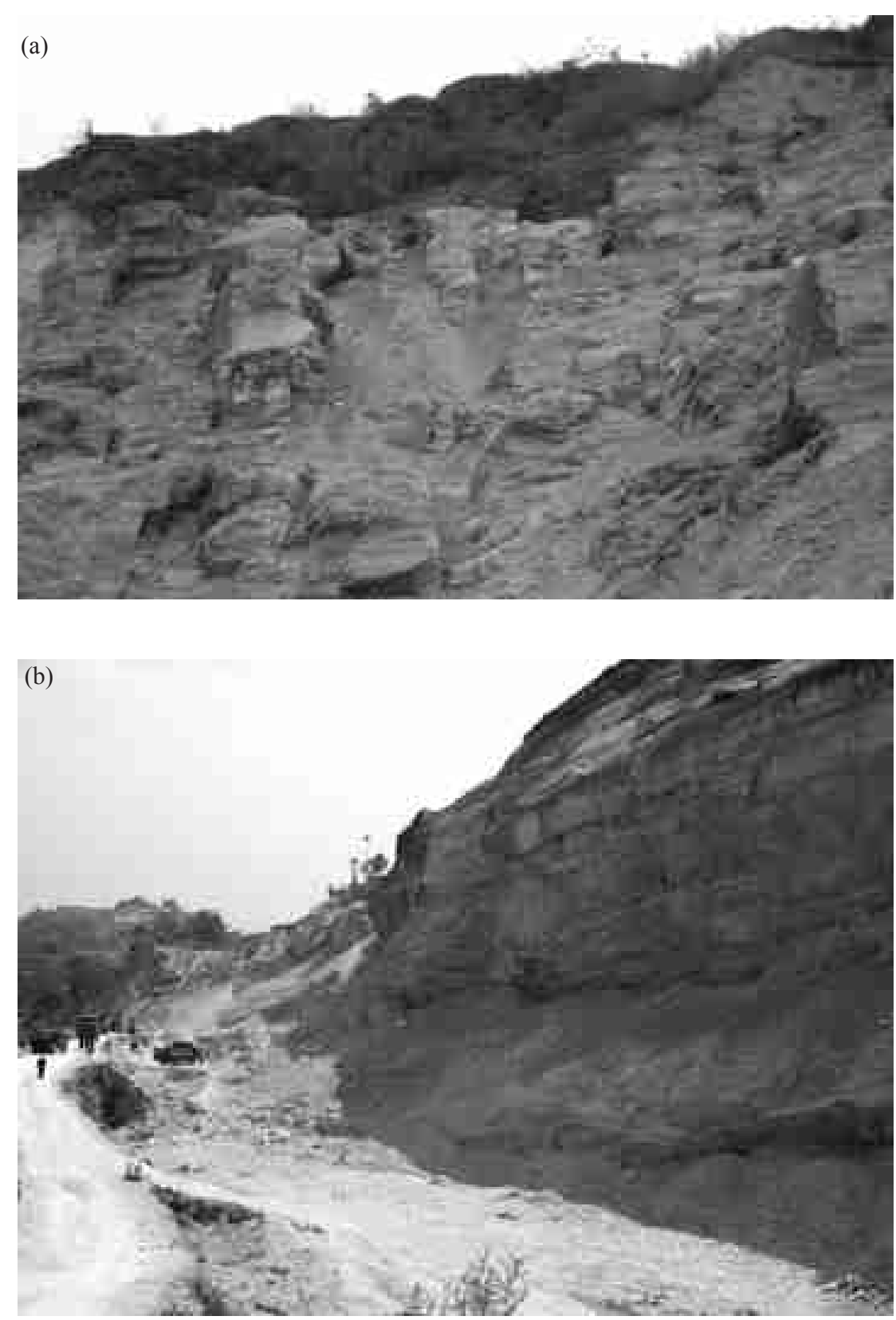

Fig. 6 Outcrop of a limestone at a quarry at the Right bank of the Jughe Khola facing north: (a) Limestones showing prominent joints, and (b) Extension of limestone outcrop in the quarry site 
are persistent and their roughness value ranges from 6 to 12 according to roughness scale of Barton and Choubey (1977). Joint separation ranges from 0.1 $\mathrm{mm}$ to $>20 \mathrm{~mm}$. Spaces may be empty, partially filled or completely filled with silty clay and vegetation. Most of the rocks on the outer surface fall in grade II and III while inner excavating fall on grade IB. Therefore, the rocks in study area are faintly weathered to moderately weathered according to weathering classification of Geological Society of London (1770). Induration of the limestone ranges from H3-H4 i.e. indurated to strongly indurated.

\section{PETROGRAPHIC ANALYSES}

Altogether 33 thin sections were prepared. Thirteen sections were coloured so that pore spaces in the rocks could be studied. Thirteen stratified samples were prepared to study the lateral variation in texture and composition of the rocks, and other seven thin sections were prepared from bulk sample area. Except coloured sections, all other thin sections were stained for separating calcite and dolomite by Dickson (1966) method for staining carbonates. Massive purple to royal blue colour on staining confirms that all the sections contain ferroan calcite. No coloured spaces in the thin sections except in some fracture shows that limestones have exceptional pore spaces and low porosity.

\section{Composition of samples}

Compositional analysis of the thin sections by using the petrographic microscope and a scion image analyzer provides that in most of the sections are composed of calcite and quartz grains with few grains of feldspar, mica and heavy minerals such as pyrite.

On the basis of percentage chemical composition and grain size parameters according to Clark and Walker (1977), rock samples have been classified in to three sub groups, i.e., crystalline limestone, siliceous limestone and calcareous siltstone (Table 2).

\section{Crystalline limestone}

Crystalline limestone contains more than 50\% carbonate mineral and show uniformity in crystal size (Fig. 7a). Samples BR1 and BR3 are crystalline varieties of limestone. Crystalline limestones are highly indurated and have high unconfined compressive strength. In outcrops, these limestones are thick bedded, light grey, coarsely crystalline with

Table 1: Rock mass characteristics

\begin{tabular}{|c|c|c|c|c|c|c|c|c|}
\hline $\begin{array}{c}\text { Sample } \\
\text { no. }\end{array}$ & $\begin{array}{l}\text { Weathering } \\
\text { grade }\end{array}$ & Discontinuities & Dip dir./amount & Persistency & Spacing & Width & Roughness & Infilling materials \\
\hline \multirow[t]{3}{*}{1} & II & Bedding & $207 / 879$ & Continuous & $0.2-1 \mathrm{~m}$ & $0.1-1 \mathrm{~mm}$ & $8-10$ & Silty clay \\
\hline & & Joint 1 & Vertical & Contd. no infill & $0.5-1.3 \mathrm{~m}$ & $1-5 \mathrm{~mm}$ & $6-8$ & silty clay+veg \\
\hline & & Joint 2 & $100 / 83$ & Noncontinuous & $0.3-1 \mathrm{~m}$ & $0.1-1 \mathrm{~mm}$ & $10-12$ & silty clay+veg \\
\hline \multirow[t]{3}{*}{2} & II-III & Bedding & $207 / 79$ & Continuous & $0.3-1 \mathrm{~m}$ & $0.1-1 \mathrm{~mm}$ & $8-10$ & Silty clay \\
\hline & & Joint 1 & $115 / 83$ & Contd. no infill & $5-30 \mathrm{~cm}$ & $1-5 \mathrm{~mm}$ & $10-12$ & silty clay+veg \\
\hline & & Joint 2 & $60 / 39$ & Noncontinuous & $1-3 m$ & $0.1-1 \mathrm{~mm}$ & $6-8$ & Silty clay \\
\hline \multirow[t]{2}{*}{3} & II & Bedding & $357 / 76$ & Continuous & $0.1-1 \mathrm{~m}$ & $<0.1 \mathrm{~mm}$ & $6-8$ & clay \\
\hline & & Joint 1 & vertical & Contd. thin infill & $5-30 \mathrm{~cm}$ & $5-20 \mathrm{~mm}$ & $8-10$ & silty clay+veg \\
\hline \multirow[t]{4}{*}{4} & IB & Bedding & $13 / 56$ & Continuous & $0.3-1 \mathrm{~m}$ & $0.1-1 \mathrm{~mm}$ & $6-8$ & silty clay+veg \\
\hline & & Joint 1 & $171 / 25$ & Contd. thick infill & $1-3 \mathrm{~m}$ & $>20 \mathrm{~mm}$ & $10-12$ & silty clay+veg \\
\hline & & Joint 2 & vertical & Noncontinuous & $5-30 \mathrm{~cm}$ & $0.1-1 \mathrm{~mm}$ & $8-10$ & clay \\
\hline & & Joint 3 & $280 / 83$ & Noncontinuous & $0.3-1 \mathrm{~m}$ & $<0.1 \mathrm{~mm}$ & $10-12$ & No infill \\
\hline \multirow[t]{2}{*}{5} & II & Bedding & $207 / 79$ & Contd. no infill & $0.3-1 \mathrm{~m}$ & $0.1-1 \mathrm{~mm}$ & $8-10$ & clay \\
\hline & & Joint 1 & Vertical & Continuous & $1-3 m$ & $1-5 \mathrm{~mm}$ & $10-12$ & silty clay+veg \\
\hline \multirow[t]{2}{*}{6} & II-III & Bedding & $22 / 75$ & Continuous & $0.1-3 \mathrm{~m}$ & $<0.1 \mathrm{~mm}$ & $6-8$ & No infill \\
\hline & & Joint 1 & $120 / 87$ & Contd. thick infill & $1-3 m$ & $>20 \mathrm{~mm}$ & $8-10$ & silty clay+veg \\
\hline \multirow[t]{3}{*}{7} & IB & Bedding & $340 / 59$ & Continuous & $1-3 \mathrm{~m}$ & $0.1-1 \mathrm{~mm}$ & $10-12$ & clay \\
\hline & & Joint 1 & vertical & Continuous & $0.3-1 \mathrm{~m}$ & $1-5 \mathrm{~mm}$ & $8-10$ & silty clay+veg \\
\hline & & Joint 2 & $115 / 83$ & Noncontinuous & $>3 \mathrm{~m}$ & $<0.1 \mathrm{~mm}$ & $6-8$ & No infill \\
\hline
\end{tabular}


Table 2: Results of the petrographic analysis of limestone and siltstone

\begin{tabular}{|c|c|c|c|c|c|c|c|c|c|c|c|}
\hline \multirow[b]{2}{*}{ Sample } & \multirow[b]{2}{*}{ Calcite } & \multicolumn{4}{|c|}{$\%$ Siliciclasts } & \multirow[b]{2}{*}{ Size $(\mathrm{mm})$} & \multirow[b]{2}{*}{ Shape } & \multirow[b]{2}{*}{ Induration } & \multicolumn{2}{|c|}{ Microstructures } & \multirow[b]{2}{*}{ Classification } \\
\hline & & Q & $\mathrm{F}$ & $\mathrm{M}$ & $\mathrm{H}$ & & & & Homogenity & Microfabric & \\
\hline BR1 & 78 & 14 & 2 & 5 & 1 & $0.032-0.132$ & Subhedral & $\mathrm{HI}$ & Homogenous & $\begin{array}{c}\text { Microlaminae } \\
\text { Massive// }\end{array}$ & $\begin{array}{l}\text { Crystalline } \\
\text { limestone }\end{array}$ \\
\hline BR2 & 55 & 40 & 2 & 2 & 1 & $0.075-0.202$ & $\begin{array}{l}\text { Anhedral } \\
\text { Elongated } \\
\text { and // to }\end{array}$ & MI & Heterogenous & polycrystalline & $\begin{array}{l}\text { Siliceous } \\
\text { limestone }\end{array}$ \\
\hline BR3 & 85 & 10 & 1 & 3 & 2 & $0.082-0.130$ & lamination & $\mathrm{HI}$ & Homogenous & $\begin{array}{c}\text { Microlaminae } \\
\text { Massive/ }\end{array}$ & $\begin{array}{l}\text { Crystalline } \\
\text { limestone }\end{array}$ \\
\hline BR4 & 40 & 48 & 5 & 3 & 4 & $0.025-0.05$ & Anhedral & MI & Heterogenous & $\begin{array}{c}\text { polycrystalline } \\
\text { Massive/ }\end{array}$ & $\begin{array}{l}\text { Calcareous } \\
\text { siltstone }\end{array}$ \\
\hline BR5 & 50 & 45 & 2 & 3 & 1 & $0.067-0.085$ & $\begin{array}{l}\text { Anhedral } \\
\text { Anhedral to }\end{array}$ & MI & Heterogenous & polycrystalline & $\begin{array}{l}\text { Calcareous } \\
\text { siltstone }\end{array}$ \\
\hline BR6 & 55 & 40 & 3 & 2 & 1 & $0.13-0.205$ & subhedral & MI & Homogenous & Microlaminae & $\begin{array}{l}\text { Siliceous } \\
\text { limestone }\end{array}$ \\
\hline BR7 & 52 & 45 & 2 & 1 & 1 & $0.082-0.105$ & Anhedral & MI & Heterogenous & Microlaminae & $\begin{array}{l}\text { Siliceous } \\
\text { limestone }\end{array}$ \\
\hline
\end{tabular}

well developed parallel lamination.

\section{Siliceous limestone}

Siliceous limestones constitute $50-70 \%$ of the total carbonate content. Generally, crystals are of sand-sized grains, and are subhedral in shape (Fig. 7b). Sample BR2, BR6 and BR7 are siliceous varieties of limestone. Siliceous limestones are moderately indurated and have moderately strong to strong unconfined compressive strength, and are thick to thin bedded, grey, and medium-crystalline.

\section{Calcareous siltstone}

Calcareous siltstones (samples BR4 and BR5) contain $10-50 \%$ total carbonate content. Grain size ranges from silt to that of the sand of anhedral shape (Fig. 7c). Calcareous siltstones are moderately indurated, and are correlated with strength of moderately strong to strong rocks (Maharjan and Tamrakar, 2003). In the field these rocks are dark grey, fine-grained, argillaceous, and cross-laminated.

Most sections show heterogeneous distribution of quartz grains interlocked with calcite. Quartz grains show polycrystalline nature under the plane polarized light and sutured contacts, which show that quartz grains are partially recrystallized.

\section{Shape analysis of aggregates}

The aggregates were studied for their shape factor $(F)$, sphericity $(\psi)$, roughness index $(\mathrm{Ru})$, roundness index (Rn), flakiness index (FI), and elongation index (EI). The results of the analyses are summarized in Table 3.

\section{Shape factor and Sphericity}

Based on the longest (a), intermediate (b) and shortest (c) axes of each grain, the shape was quantified in terms of flatness ratio $(\mathrm{p}=\mathrm{c} / \mathrm{b})$ and elongation ratio $(q=b / a)$. The $p$ and $q$ range from 0.65 to 0.79 and 0.57 to 0.71 , respectively. Shape factor $(F)$ is the ratio of $\mathrm{p} / \mathrm{q}$ and ranges from 0.99 to $1.40 \mathrm{in}$ most of the samples indicating their cubic to disc shape. However the plot of flatness and elongation ratios indicate that the most of the aggregates are cubic (Fig. 8).

The Aschenbrenner's working sphericity $(\phi)$ was calculated as:

$$
\Psi=\left\{12.8\left(p^{2} q\right)^{1 / 3}\right\} /\left\{1+p(1+q)+6\left(1+p^{2}\left(1+q^{2}\right)\right)\right\}
$$

Sphericity ranges from 0.82 to 0.90 (Table 3 ) and 

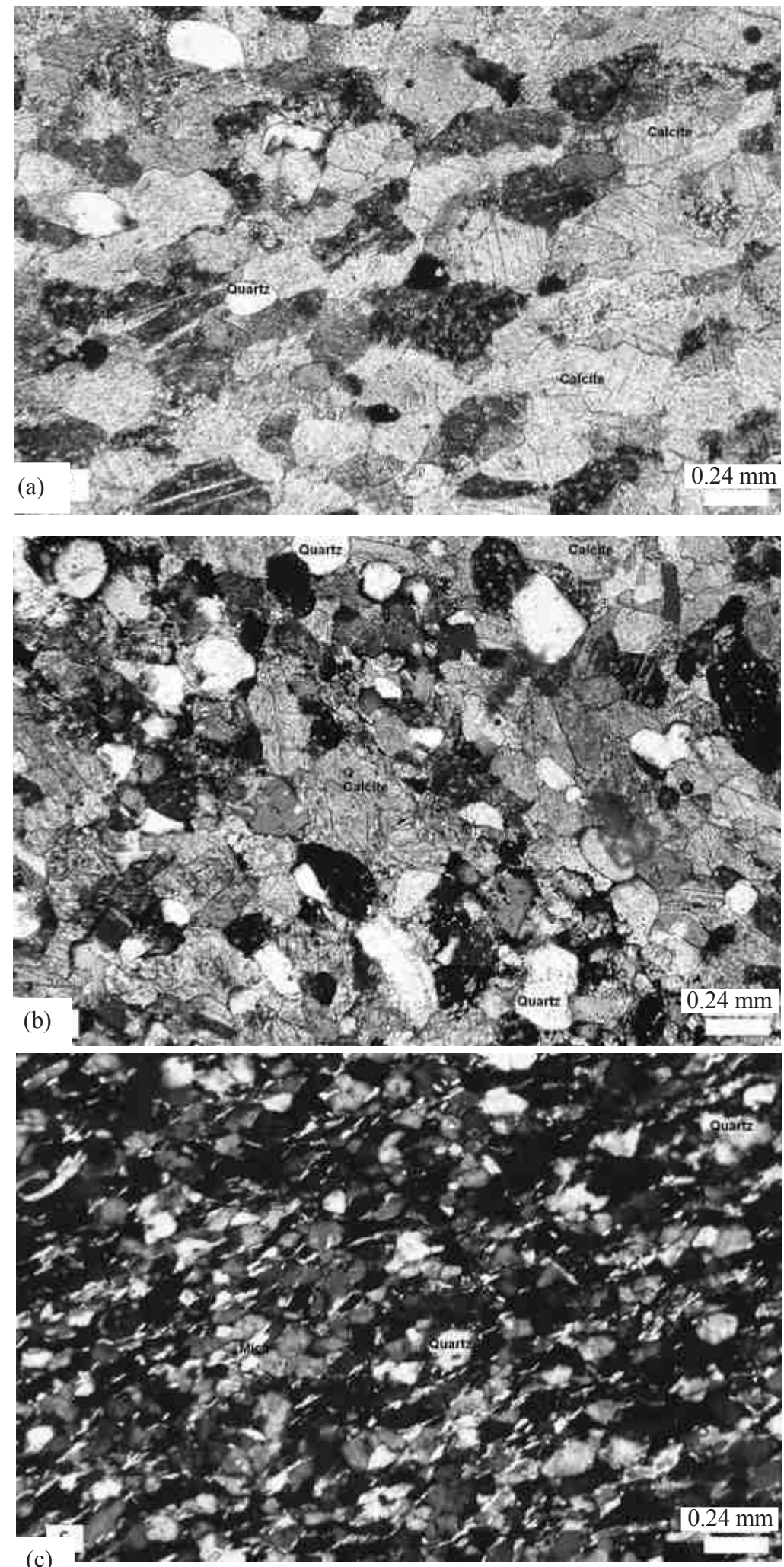

Fig. 7 Photomicrographs of limestone; (a) Crystalline limestone lacking original texture, (b) Siliceous limestone (stained) showing lamina and (c) Calcareous siltstone in which interlocked and elongate quartz grains 
Table 3: Results of the shape analysis of aggregate

\begin{tabular}{ccccccccc}
\hline Sample no. & $\begin{array}{c}\text { Elongation } \\
\text { ratio(q) }\end{array}$ & $\begin{array}{c}\text { Flatness } \\
\text { ratio }(\mathrm{p})\end{array}$ & $\begin{array}{c}\text { Shape factor } \\
(\mathrm{p} / \mathrm{q})\end{array}$ & $\begin{array}{c}\text { Sphericity } \\
(\psi)\end{array}$ & $\begin{array}{c}\text { Roughness } \\
(\mathrm{Ru})\end{array}$ & $\begin{array}{c}\text { Roundness } \\
(\mathrm{Rn})\end{array}$ & FI \% & EI \% \\
\hline BR1 & 0.69 & 0.73 & 1.1 & 0.86 & 1.36 & 54.47 & 25.03 & 75.49 \\
BR2 & 0.66 & 0.77 & 1.34 & 0.86 & 1.28 & 54.77 & 22.37 & 90.79 \\
BR3 & 0.7 & 0.79 & 1.16 & 0.90 & 1.28 & 53.33 & 22.06 & 76.03 \\
BR4 & 0.71 & 0.65 & 0.99 & 0.85 & 1.31 & 52.81 & 20.93 & 83.92 \\
BR5 & 0.65 & 0.69 & 1.1 & 0.85 & 1.32 & 53.3 & 14.74 & 89.95 \\
BR6 & 0.7 & 0.72 & 1.06 & 0.87 & 1.32 & 53.51 & 1.61 & 86.68 \\
BR7 & 0.57 & 0.72 & 1.4 & 0.82 & 1.4 & 52.65 & 16.02 & 87.61 \\
\hline
\end{tabular}

shows that it possesses high sphericity.

\section{Roughness and roundness}

Roughness and roundness indices of Janno (1998) were measured using NIH Scion image analyzer and calculated using following relations:

\section{Roughness index $(R u)=P / P_{c}$ \\ Roundness index $(R n)=4 \pi A / P^{2}$}

where, $\mathrm{A}$ is area of particle, $\mathrm{P}$ is perimeter, and $\mathrm{Pc}$ is a convex perimeter.

For a smooth material, the roughness index $(\mathrm{Ru})$ is equal to unity. As roughness increases, $\mathrm{Ru}$ also increases. Increase in $\mathrm{Ru}$ shows that the aggregates have sufficient surface roughness and have good workability (Kaplan 1961; Neville 1996).

The roundness index $(\mathrm{Rn})$ of a perfect circle is 100. As a material becomes angular, Rn decreases (Janno 1998). Rounded aggregates produce significantly higher permanent deformation than the angular ones. Internal frictional angle increases with the increasing angularity and surface roughness (Holtz and Kovacs 1981).

Roughness index ranges from 1.28 to 1.40 whereas roundness index of the aggregates here varies from 52.65 to 54.77 (Table 3), which shows that aggregates have high roughness and moderate roundness indices.

\section{Flakiness and elongation index}

Flakiness and elongation indices were determined using the methods of determining particle shape by BS 812 (BSI 1989). During FI test, aggregate sample was sieved through different sieve sizes, at least 200 pieces of each fraction were taken, weighed and allowed to pass through the selected slot-size which had width equal to 0.6 times the mean dimension. The fraction of samples passing through the thickness gauge was weighed and FI was calculated as below:

$$
\text { Flakiness index }(F I)=\left(W_{T} / W\right) 100(\%)
$$

where, $\mathrm{W}_{\mathrm{T}}$ is the weight of the aggregate passing through the slot and $\mathrm{W}$ is the total weight of the test sample.

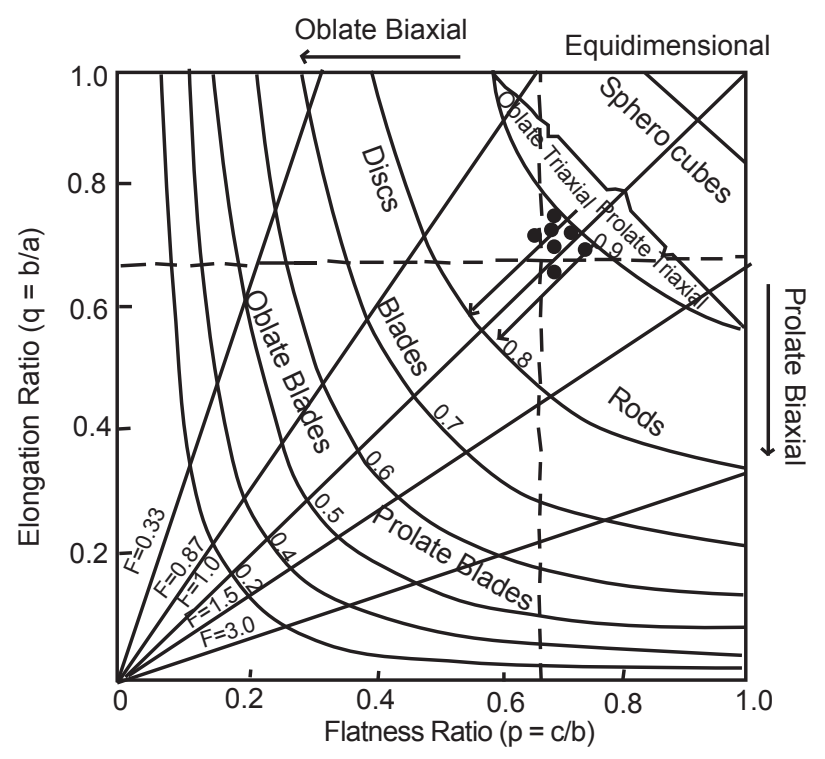

Fig. 8 Shape diagram indicating mean forms of aggregate samples 
During elongation index test, aggregate was allowed to pass through the length gauge whose longest dimension was greater than 1.8 times their mean dimension. The fraction, which did not pass through the gauge, was weighed and EI was calculated as:

\section{Elongation index $(E I)=\left(W_{L} / W\right) 100(\%)$}

where, $\mathrm{W}_{\mathrm{L}}$ is weight of aggregate retained in the length gauge and $\mathrm{W}$ is the total weight of test sample.

Low percentage of FI shows that aggregate contains only a few flat grains and high percentage of EI indicates the presence of only small number of elongated grains. Flakiness index of the test samples varies from $14 \%$ to $25 \%$ and elongation index varies from 75.49 to $90.79 \%$ (Table 3 ) indicating that the samples are not so flat and elongated.

\section{ANALYSES OF PHYSICAL AND MECHANICAL PROPERTIES}

The aggregates were studied for their dry density, water absorption value (WAV), aggregate crushing value (ACV), aggregate impact value (AIV), Los Angeles Abrasion (LAA) and California Bearing Ratio (CBR). The results of these analyses are summarized in Table 4.

\section{Dry density and water absorption}

The physical properties of aggregate such as dry density and water absorption value were determined for cylindrical samples according to caliper and saturation method (ISRM 1979).

Dry density of samples ranges from $2495 \mathrm{Kg} / \mathrm{m}^{3}$ to $2658 \mathrm{Kg} / \mathrm{m}^{3}$ with an average value of $2600 \mathrm{Kg} / \mathrm{m}^{3}$. Water absorption value (WAV) ranges from 0.20 to $0.67 \%$ which is less than that of the standard (Table 4). This shows that samples have low effective porosity.

\section{Crushing and impact values}

Aggregate crushing value (ACV) and Aggregate impact value (AIV) were determined using a compression testing machine and hammer respectively following ASTM (1979). ACV provides the relative measure of resistance to crushing under the gradually applied compressive load while AIV is the resistance of the stones to fracture under repeated impact. ACV and AIV were calculated using the equations:

$$
\begin{aligned}
& A C V=\left(W_{2} / W_{l}\right) 100(\%) \\
& A I V=\left(W_{3} / W_{l}\right) 100(\%)
\end{aligned}
$$

where, W1 is the total weight of the dry sample (grams), $\mathrm{W}_{2}$ is the weight of the aggregate passing $4.75 \mathrm{~mm}$ sieve, and $\mathrm{W}_{3}$ is the weight of an aggregate passing on $2.36 \mathrm{~mm}$

ACV ranges from 20 to $30 \%$ (Table 4) which indicates that aggregates are strong, as a crushed fraction is low. The results shows that the AIV lies

\begin{tabular}{|c|c|c|c|c|c|c|c|c|}
\hline $\begin{array}{c}\text { Sample } \\
\text { no. }\end{array}$ & WAV\% & $\begin{array}{c}\text { Dry density } \\
\left(\mathrm{Kg} / \mathrm{m}^{3}\right)\end{array}$ & LAA $\%$ & AIV $\%$ & $\mathrm{ACV} \%$ & SSV\% & CBR \% & Compositional group \\
\hline BR1 & 0.36 & 2594 & 30.3 & 10.04 & 24.16 & 8.79 & \multirow{3}{*}{61.23} & Crystalline limestone \\
\hline BR2 & 0.29 & 2615 & 30.0 & 11.08 & 25.83 & 10.32 & & Siliceous limestone \\
\hline BR3 & 0.20 & 2652 & 28.4 & 12.17 & 25.16 & 8.57 & & Crystalline limestone \\
\hline BR4 & 0.52 & 2536 & 29.2 & 12.12 & 26.50 & 10.1 & \multirow{4}{*}{61.00} & Calcareous siltstone \\
\hline BR5 & 0.26 & 2626 & 30.2 & 14.05 & 26.33 & 6.81 & & Calcareous siltstone \\
\hline BR6 & 0.31 & 2605 & 28.0 & 14.12 & 26.16 & 4.37 & & Siliceous limestone \\
\hline BR7 & 0.68 & 2567 & 26.8 & 11.45 & 22.00 & 11.64 & & Siliceous limestone \\
\hline
\end{tabular}

Table 4: Results of the physical, mechanical and chemical analysis of limestone aggregate 
between 10 to $20 \%$, which is under the standard value of ASTM, $10-20 \%$, BS $<20 \%$ and NRS (NRS) $<$ $30 \%$. Therefore the entire sample indicates strong enough to resists impact and is appropriate for both base and sub base course.

\section{Los Angeles abrasion value}

Hardness and toughness of aggregates associated together are often carried out in the Los Angeles Abrasion test (LAA). The principle of the test is to find the percentage wear due to the relative rubbing action between the aggregates and the steel balls used as abrasive charge. This test has been standardized by the ASTM C: 535 (ASTM 1981). LAA was calculated using the following equation:

$$
L A A=\left(W_{1}-W_{2} / W_{1}\right) 100(\%)
$$

where, $\mathrm{W}_{1}$ is weight of original sample and $\mathrm{W}_{2}$ is weight of aggregate retained on $1.70 \mathrm{~mm}$ IS sieve after test.

The Los Angles abrasion value varies from 26 to $30 \%$ (Table 4 ) which is under the acceptable limit of NRS (DOR 2001) for base and sub base course.

\section{California bearing ratio test}

It is a measure of resistance of materials to penetration of standard plunger under controlled density and moisture conditions. The test may be conducted in re-moulded or undistributed specimen in the laboratory following five layers compaction. The load values noted for each penetration level were divided by the area of the loading plunger (19.64 $\mathrm{cm}^{2}$ ) to obtain the pressure or unit load values on a loading plunger. Load values corresponding to 2.5 and $5.0 \mathrm{~mm}$ penetration values were found and calculated using a following equation:

$$
C B R=P_{d p l} / P_{a p l} .100(\%)
$$

where, $\mathrm{P}_{\mathrm{dpl}}=$ unit load carried at different penetration level and $\mathrm{P}_{\mathrm{apl}}=$ unit load carried above penetration level.

CBR is determined for base course and sub base to evaluate the foundation, stability (resistance against load) and stress distribution properties of aggregates in these layers. According to NRS (DOR 2001) minimum CBR value for base course is $80 \%$ and sub base is $60 \%$. In the present analysis for two composite samples (a set of BR1, BR2 and BR3, and a set of BR4, BR5, BR6 and BR7), the obtained CBR values are $61.23 \%$ and $61.00 \%$ (Table 4 ) which are under the acceptable values for base course and sub base course. The obtained values were from Proctor compaction method. The values would be approximately equal to $80 \%$ if the test were done by heavy compaction. This means that the tested samples are suitable for sub grade and granular sub base course.

\section{ANALYSES OF CHEMICAL PROPERTIES}

\section{Sodium sulphate soundness value}

Soundness test is a good measure of how resistant an aggregate is to chemical weathering. Soundness test determines the resistance to disintegration of aggregates due to alternate cycles of dry and wet condition. Sample of size 10-14 $\mathrm{mm}$ and mass 455 gm for the test was washed with distilled water and oven dried at $105-110^{\circ} \mathrm{C}$. A saturated solution of sodium sulphate was produced with the density of $1.32 \mathrm{~g} / \mathrm{cm}^{-3}$. The test specimen were then subjected to five 48 hours immersion and drying cycles. The sodium sulphate soundness value was calculated as:

$$
S S V=\left(W_{1 \mathrm{ssv}}-W_{2 \mathrm{ssv}} / W_{1 \mathrm{ssv}}\right) 100(\%)
$$

where, $\mathrm{W}_{1 \mathrm{ssv}}$ is the initial weight of the sample and $\mathrm{W}_{2 \mathrm{ssv}}$ is the weight retained on $10 \mathrm{~mm}$ after the test.

SSV of samples varies from 6 to $12 \%$ which is under the acceptable range of base course and sub base course (Table 4). SSV less than $12 \%$ means the aggregates samples are sound and resistant against chemical weathering and frost susceptibility.

\section{$\mathrm{CaO} / \mathrm{MgO}$ ratio}

The samples were tested at Brij Cement Industries Pvt. Ltd., Bhairhawa, following the titration method. $\mathrm{The} \mathrm{CaO} / \mathrm{MgO}$ ratio ranges from 4.59 to 61.25 . It was highest in siliceous limestone and least in calcareous siltstone. 


\section{EVALUATION OF CRUSHED ROCK AGGREGATES}

Overall evaluation of crushed-limestone and siltstone aggregates for road can be made by comparing the obtained value with different standards which are listed in Table 5.

Limestones and siltstones differ in percentage carbonate content and siliciclastic components. Their physical, mechanical and chemical properties do not vary exceeding the NRS (DOR 2001), which suggests that the aggregates are suitable for unbound pavements and can make performance better than those having uniform composition.

Weathering grade of the rock of quarry area varies from IB to II which means that the rock is faintly to slightly weathered and can be used for road aggregates.

The surface features such as angular shape and rough crystalline texture are the valuable guides relative to the internal frictional properties of an aggregate which resists the movement of aggregates past each other and considered as excellent road aggregates.
On the basis of characters such as spacing of joints, and persistence, limestones and siltstones are medium strength rock mass which can be only extracted by blasting and fracturing.

According to NRS (DOR 2001), the shape of the aggregates i.e. flakiness index (FI) should not exceed $25 \%$. As FI values of all the samples are less than 25 $\%$, they lie under the acceptable limit of the entire standard. FI should not exceed the given range of value $25-30$ as rounded aggregates are preferred in cement concrete road (rigid pavement) construction because workability of concrete improves and angular shape of particles are desirable for granular base course due to increased stability derived from better interlocking.

WAV values of the samples vary from $0.20-0.67$. This means that the limestone has very low effective porosity. WAV is under the acceptable value of ASTM: C33 (ASTM 1994) i.e. $<3 \%$, and $<1 \%$ according to BS: 812 (BSI 1985) for road surfacing, while values of up to $4 \%$ may be accepted in road bases.

ACV ranges from $22-26 \%$ which means that rocks are strong enough to resist fracturing under an applied

Table 5: Evaluation of crushed-rock for unbound pavement

\begin{tabular}{|c|c|c|c|c|c|c|c|}
\hline \multirow{2}{*}{\multicolumn{2}{|c|}{ Properties }} & \multirow{2}{*}{ Obtained value } & \multirow{2}{*}{$\begin{array}{c}\text { ASTM C33 } \\
\text { (ASTM } \\
1994)\end{array}$} & \multirow{2}{*}{$\begin{array}{c}\text { BS } 812 \\
(\text { BSI 1985) }\end{array}$} & \multicolumn{2}{|c|}{$\begin{array}{l}\text { Nepal Road Standard } \\
\text { (DOR 2001) }\end{array}$} & \multirow[b]{2}{*}{ Remarks } \\
\hline & & & & & $\begin{array}{c}\text { Base } \\
\text { course }\end{array}$ & $\begin{array}{l}\text { Sub base } \\
\text { course }\end{array}$ & \\
\hline \multirow[t]{3}{*}{ Petrographic } & FI \% & $16.06-25.02$ & & & 25 & 30 & $\begin{array}{l}\text { Appropriate for both base and sub base } \\
\text { courses }\end{array}$ \\
\hline & EI \% & $10.07-25.50$ & & & & & Good road aggregates \\
\hline & WAV \% & $0.199-0.676$ & $<3$ & $<1$ & $<4$ & $<4$ & $\begin{array}{l}\text { Low effective porosity and acts as good } \\
\text { road aggregates }\end{array}$ \\
\hline \multirow[t]{3}{*}{ Physical } & DD $\%$ & $0.536-0.652$ & $2-3.1$ & & 2.622 & 2.622 & $\begin{array}{l}\text { Average density of limestone for } \\
\text { aggregates }\end{array}$ \\
\hline & $\mathrm{ACV} \%$ & $22.00-26.50$ & & & $<30$ & $<30$ & Strong as crushing value is low \\
\hline & AIV \% & $10.04-14.12$ & $10-20.5$ & $<20$ & $20-25$ & 30 & $\begin{array}{l}\text { Strong enough to resist impact for both } \\
\text { course }\end{array}$ \\
\hline \multirow[t]{2}{*}{ Mechanical } & LAA $\%$ & $26.80-30.30$ & $<30$ & & $30-35$ & 40 & Best for road and concrete \\
\hline & CBR \% & 61 & & & 80 & 60 & Appropriate for sub base course \\
\hline Chemical & SSV \% & $4.37-11.64$ & $<10$ & $<10$ & 12 & 12 & Chemically sound for both courses \\
\hline
\end{tabular}


compressive load. Materials with values greater than $35 \%$ are very weak to be utilized in a pavement.

LAA values of the limestones and siltstones obtained from the tests varies from 27 to $30 \%$ indicating that the aggregates are acceptable for road base and sub base courses, under the criteria $(<40 \%)$ of NRS (DOR 2001).

AIV, the toughness value of an aggregate obtained varies from $10-14 \%$, is under the acceptable limit of NRS (DOR 2001). Acceptable values for AIV for base course and sub base course are less than 30\% according to ASTM: C33 (ASTM 1994) and BS: 812 (1985). Sodium soundness value, useful to access the resistance of an aggregate to weathering is within the acceptable range of $12 \%$ for road base and sub base after 5 cycles ASTM: C33 (ASTM 1994). Therefore the aggregate samples are sound and resistant against chemical weathering and frost susceptibility.

CBR values obtained for tested samples $(61.23 \%$ and $61.00 \%$ ) are under acceptable values for road aggregates according to NRS (DOR 2001). The specific gravity of aggregate normally used in road construction ranges from about 2.5 to 3.0 with an average value of about 2.68 (Khanna and Justo 2004). Obtained value of dry density varies from 2495-2658 $\mathrm{kg} / \mathrm{m}^{3}$ which is under the acceptable range.

\section{Reserves of rock outcrops at quarry site}

The vertical cross-section method was applied for calculating the reserve of the deposit at the quarry site. Three vertical cross-sections oblique to the strike of the bedding planes of the deposit were drawn at the scale 1: 100 scale, and the strike length of 100 metres each was taken. Then the tonnage factor of 2.6 was considered to estimate the reserve of the deposit. The total minable reserve is 26.42 million tonnes.

\section{CONCLUSIONS}

Highly fractured, slight to moderately weathered, medium to thick bedded rock masses with prominent two sets of joints parallel and perpendicular to the bedding planes make the extraction of rock easy during mining.

Petrographically, three distinct rock varieties have been recognised as crystalline limestone, siliceous limestone and calcareous siltstone. The crushed-rock aggregates from these rock types yield fragments with high sphericity, roughness index more than 1 and moderate roundness index, suggesting that aggregates possess character of good workability considering to shape which they have yielded.

Water absorption value, average dry density, ACV, AIV, LAA value, CBR and SSV within the given range of NRS, British Standard and American standard showing that aggregates perform better for unbound pavement in roads.

The total reserve of the delposit containing limestones and siltstones at the quarry site was estimated to be 26.42 million tonnes.

\section{ACKNOWLEDGEMENTS}

Authors are thankful to Institute of Engineering and Central Department of Geology for providing laboratory facilities. Authors thank Durga Prasad Awasti for comments and suggestions.

\section{REFERENCES}

ASTM, 1979. Standard method of test for triaxial compressive strength of undrained rock core specimen without pore pressure measurements. American Society of Testing Material, Annual book of ASTM standard, $632 \mathrm{p}$.

ASTM, 1981. Test for resistance to degradation of large sized coarse aggregates by abrasion and impacts in the Los Angeles Machine.

ASTM, 1994. Standard specification for transportation materials, and method of sampling, ASTM: C33. Washington DC.

Barton, N. and Choubey, V., 1977. The shear of rock joints in theory and practice. v. 10, pp. 1-54.

British Standard Institution, 1985. Specification for constituent materials and mixes. BS 812 .

British Standard Institution, 1989. Methods of determination of particle shape. BS 812 part 1, BSI, London.

Clarke, A.R. and Walker, B.F., 1977. A proposed scheme for the classification and nomenclature for use in the engineering description of middle eastern sedimentary rocks. Geotechnique, v. 27, pp. 93-99.

Dhakal, G.P., Kodma J. and Goto J., 2006. FreezingThawing effect and slake durability of some rocks from cold regions of Nepal and Japan, Nepal Geological Society, v.33, pp.45-54.

Dickson, J.A.D., 1966. Carbonate identification and genesis as revealed by staining. J. Sed. Petrol., v. 36, pp. 491-505. 
DOR, 2001. Standard Specifications for Road and Bridge works, Reports of Ministry of Physical Planning and Works, pp.600-1200.

Geological Society Engineering Group Working Party Report, 1977. The description of rock masses for engineering purposes. Quarterly Journal of Engineering Geology, v. 10, p p. 355-388. doi:10.1144/GSL.QJEG.1977.010.04.01

Holtz, R.D and Kovacs, W. D., 1981. An introduction to Geotechnical engineering, Eaglewood Cliffs, New Jersy, Prentice-Hall, Inc.

ISRM, 1979. Suggested methods for determining water content, porosity, density, asorption and related properties and swelling and slake durability index properties. International Society of Rock Mechanics. Comm. On standardization of Laboratory and Field Test., Intl. Jour. Rock Mech. Min. Sci. and Geomech., Abstract, v. 16, pp. 141-156. doi:10.1016/01489062(79)90191-8

Janno,V.C., 1998. Quantification of Shape, Angularity, and surface texture of Base Course Materials, US Army Crops of Engineers, Special Reports 98-1, pp. 1-22.

Kaplan, M.F., 1961. Crack propagation and fracture of concrete,Journal American concrete Institute, v. 58, pp. 509-610.

Khanna, S.K. and Justo CEG, 2004. Highway and Material Testing a Laboratory Mannual, Nemchand and Bros, Roorkee Press, pp.2-94.

Maharjan, D.K and Tamrakar N.K., 2003. Quality of Siltstones for Concrete Aggregates from Nallu Khola
Area, Kathmandu Nepal, Geological Society, v. 30, pp.167-176.

Maharjan, S. and Tamrakar, N.K., 2007. Study of Gravel of the Narayani and Rapti River for Construction Materials, Bulletin of Department of Geology, v. 10, pp. 99-106.

Nepal Standard and Measurement Bureau, 1994. Specification for aggregates (NS-297-2050) U.D.C N620, 113p.

Neville, A.M., 1996. Properties of concrete, Fourth edition, Addision Wesley Longman, Essex, England.

Stocklin, J. and Bhattarai, K.D., 1980. Geology of Nepal and Its Regional Frame, Journal of the Geological society of London, v. 137, pp. 1-34.

Tamrakar, N.K., Yokota, S. and Nakamura, M., 1999, Some mechanical properties of the Siwalik sandstones and their relation to petrographic properties, Geoscience Report of Shimane University, v.18, pp. 41-54.

Tamrakar, N.K., Yokota, S. and Shrestha, S.D., 2007. Relationships among mechanical, physical and petrographic properties of Siwalik sandstones, Central Nepal Sub-Himalayas. Engineering Geology, v. 90, pp. 105-123. doi:10.1016/j.enggeo.2006.10.005

Thapaliya, A., 2005. Study of the quality assessment, reserve estimation and mining techniques of dimension stones of Kharpa deposit, Central Nepal. M. Sc. dissertation submitted to Central Department of Geology, Tribhuvan University, 64p.

TRR, 1990. Design and evaluation of Rigid and Flexible Pavements, Record number 1286, pp.7-11. 